Nigeria, and has been guest lecturer in the University of Toronto and at a number of American universities. $\mathrm{He}$ is at present senior pathologist and head of the Laboratory Services of Sierra Leone.

\section{Recruitment of Teachers in Britain}

IN replying for the Government in an adjournment debate in the House of Commons on the supply of teachers of mathematics, which was opened by $\mathrm{Mr}$. A. Skeffington and Mrs. E. White on May 9, the Parliamentary Secretary to the Ministry of Education, Mr. K. Thompson, said that a survey carried out in the schools in March 1959 showed that there are 5,100 people with honours degrees teaching mathematics in maintained schools, and 4,500 of these were in 2,600 maintained secondary schools with General Certificate of Education courses in mathematics or science, in which at that time there were 250 vacancies for honours graduates to teach mathematics. In these 2,600 schools there are also 3,250 non-graduate specialists teaching to General Certificate of Education standards. Mr. Thompson pointed out that of honours mathematies graduates from British universities, two-thirds already go into the educational system at some point and the universities are increasing their output. If the proportion recruited for teaching could be increased, this would be done. He also stated that during the period when teaching qualified a man for deferment from National Service, there was a net gain of about 500 honours graduates into the teaching profession, and that this modest gain had continued since 1957 when honours graduates had been completely free to choose between industry and the teaching profession. Mr. Thompson thought that the debate had not been completely fair to those coming from training colleges in Britain : he is confident that many of them are quite capable of teaching mathematical subjects and some of the sciences to Ordinary level General Certificate of Education standard with success, and some of them would be able to take these subjects at a higher level. Apart from his reference to attempts to attract more university graduates into the schools, Mr. Thompson stressed the need to attract more married women to come back into teaching either full-time or part-time, and he referred to the refresher and short courses in mathematics promoted by the Ministry, and to the 106,000 Ordinary level and 21,000 Advanced level passes from maintained secondary schools, compared with 71,000 and 13,000 , respectively, in 1954 .

\section{British Books for Export}

IN a written answer in the House of Commons on May 9, the Chancellor of the Duchy of Lancaster, Dr. Charles Hill, stated that the Advisory Committee on the Selection of Low.Priced Books for Export has made good progress, and he understood that the Committee will shortly recommend its first list from the 2,000 titles put forward by publishers and others to the Ministers concerned. The Advisory Committee is also studying a first list of some twenty. five scientific and technical text-books for issue in low-priced editions for university and college libraries, instructors and students. The Government has decided to give a measure of priority to university text-books in view of the importance attached by the Commonwealth Educational Conference to the supply of books of educational, scientific and technical value. Initially, the arrangement will be applied in
India, and subject to negotiations with publishers, it is hoped that low-priced editions of text-books will be made available for distribution through normal trade channels in India by December next. The size of editions will depend upon demand, among other factors, but the Government has in mind editions of up to 5,000 copies of the more specialized and advanced university text-books.

\section{Dental Research in Britain}

IN answer to a question about dental research in the House of Commons on May 9, Mr. D. WalkerSmith, Minister of Health, as representing the Minister for Science, said that current annual expenditure on dental research by the Medical Research Council exceeds $£ 35,000$, and that at least one quarter of the annual expenditure of $\$ 750,000$ of the university dentistry departments is spent on research. The Minister is not satisfied with the scale of dental research in Britain, and he attributes the position to lack of interest and enthusiasm on the part of dentists and graduates in science.

\section{European Co-operation for Science}

A MAJOR project in international co-operation in science education is to be launched as the result of an agreement signed between the Minister of Education and the Organization for European Economic Cooperation. The project will consist of a series of films aimed at stimulating the interest of young people in scientific subjects and made by a number of national organizations. The organizations are: the Educational Foundation for Visual Aids (United Kingdom); Institut Pedagogique National (France); Institut für Film und Bild (Germany); Statens Filmcentral (Denmark) ; Statens Filmsentral (Norway); Nederlandse Onderwijs Film (Holland). The contribution of the United Kingdom will be a film on 'Faraday' and the others are: "The Atomic Age" (Denmark); "Fight against Bacteria" (France) ; "Discovery of the Rare Gases" (Holland) ; "The Story of X-Rays" (Germany) ; and "The Story of Electrochemistry" (Norway). The scheme, initiated by the United Kingdom, received the full support of the national organizations represented on the International Council for Educational Films. It has been made possible by financial help from the Organization for European Economic Co-operation which is contributing half the cost, the remainder being provided by the national organizations already mentioned. The project will be organized by the Educational Foundation for Visual Aids. When complete, the films will be available to all schools in the member countries of the Organization for European Economic Co-operation.

\section{The Association of Universities of the British Commonwealth}

The report of the Executive Council of the Association of Universities of the British Commonwealth for the year ended July 31, 1959, includes the usual particulars of appointments in which the Association was asked to act in one way or another (pp. 28. London : Association of Universities of the British Commonwealth, 1959). These totalled 720, compared with 651 in 1957-58, and the office dealt with 4,896 inquiries, of which 4,260 related to advertised appointments. Eighty advisory committees were convened and reports sent to the universities concerned on 139 candidates. Of the 115 candidates making application through the Association whose 